Old Dominion University ODU Digital Commons

Fall 2013

\title{
The Crisis in State Highway Finances: Its Roots, Current Effects, and Some Possible Remedies
}

Juita-Elena Yusuf

Old Dominion University, jyusuf@odu.edu

Lenahan O'Connell

Follow this and additional works at: https://digitalcommons.odu.edu/publicservice_pubs

Part of the Finance and Financial Management Commons, Infrastructure Commons, Taxation Commons, and the Transportation Commons

\section{Repository Citation}

Yusuf, Juita-Elena and O'Connell, Lenahan, "The Crisis in State Highway Finances: Its Roots, Current Effects, and Some Possible Remedies" (2013). School of Public Service Faculty Publications. 18.

https://digitalcommons.odu.edu/publicservice_pubs/18

\section{Original Publication Citation}

Yusuf, J.-E., \& O'Connel, L. (2013). The crisis in state highway finances: Its roots, current effects, and some possible remedies. Journal of Public Budgeting, Accounting \& Financial Management, 25(3), 502-521.

This Article is brought to you for free and open access by the School of Public Service at ODU Digital Commons. It has been accepted for inclusion in School of Public Service Faculty Publications by an authorized administrator of ODU Digital Commons. For more information, please contact digitalcommons@odu.edu. 


\title{
THE CRISIS IN STATE HIGHWAY FINANCES: ITS ROOTS, CURRENT EFFECTS, AND SOME POSSIBLE REMEDIES
}

\author{
Juita-Elena (Wie) Yusuf and Lenahan O'Connell*
}

\begin{abstract}
This paper focuses on the American states and the sources of the expanding structural imbalance between their highway-related revenues on the one hand and expenditures for transportation infrastructure needs on the other. The paper describes the roots of the funding problem over recent decades, looks at some of the responses taken at the state and federal level, and discusses their inherent limitations as solutions to this funding crisis. The paper also presents several policy recommendations for increasing revenues. We demonstrate that a variable rate gas tax indexed to the construction cost index and improvements in automobile fuel efficiency and a tax on large commercial trucks based on equivalent standard axle loads (an esal-mile tax) would more effectively fund the state highway system and reduce the need for more spending on maintenance and new facilities.
\end{abstract}

\section{INTRODUCTION}

The federal, state and local governments in the U.S. are facing a crisis in transportation finance and highway finance specifically. One

* Juita-Elena (Wie) Yusuf, Ph.D., is an Assistant Professor, Department of Urban Studies and Public Administration, Old Dominion University. Her research interests are in public budgeting and financial management, with a particular interest in transportation finance, and transparency, accountability and public participation. Lenahan O'Connell, Ph.D., is a Senior Research Associate, Kentucky Transportation Center. His research areas are transportation policy, finance and planning, mechanisms for accountability, and smart growth policy.

Copyright $\odot 2013$ by PrAcademics Press 
factor contributing to the shortage of transportation funding is wellknown-fuel tax revenues are declining as cars and small trucks become more fuel efficient and electric and hybrid vehicles join the nation's fleet. In 1975, the average automobile fuel efficiency was 13.9 miles per gallon (mpg), compared to $21.1 \mathrm{mpg}$ in 1995 and $22.6 \mathrm{mpg}$ in 2008 (Bureau of Transportation Statistics, 2010). But the funding crisis has other sources and a comprehensive response to this crisis will require various policy changes.

This paper focuses on the states and the sources of the expanding structural imbalance between states' highway-related revenues on the one hand and their expenditures for transportation infrastructure needs on the other. We specifically ask: what structural factors are contributing to declining fiscal sustainability in state highway finance? Much of the nation's road building and maintenance is funded by state and local governments. Several sources of funding are intergovernmental, with the federal government transferring money to the states from the federal highway trust fund and the states providing funds for local roads from the state highway fund-a major component of both funds is the gas tax. Unfortunately for the states, the federal highway trust fund continues to be quickly depleted, which will negatively affect the extensive financial support provided by the federal government to states and localities in the form of intergovernmental transfers. This will exacerbate a funding problem with roots in the sprawling development of recent decades and the related upsurge in vehicle ownership and miles travelled on the nation's highways and roads. As we demonstrate in this paper, the states currently have more lane miles of roadways, serving many more vehicles, but with less revenue per lane mile to devote to their infrastructure given the size of the system and the increased wear and tear from heavy traffic. Moreover, congestion continues to worsen and the demand for more transportation infrastructure is strong.

This paper is structured to address three issues. The first issue involves the roots of the funding problem over the past 30 years. The second looks at some of the responses taken at the state, federal, and local levels and discusses their inherent limitations as solutions to the funding crisis. The last section presents several policy recommendations targeted at increasing revenue. Throughout our analysis, we adhere to two fundamental ideas: (1) highway policy and 
highway finance should seek to reduce environmental externalities and unnecessary construction; and (2) the best way to accomplish that end is to maximize, to the extent feasible, a direct connection between highway use by drivers and the payment of taxes and fees. That is, as much as possible, the users who benefit from highway infrastructure should pay in proportion to their use and the external costs generated by that use.

Brown and co-authors (Brown et al., 1999) recommend user fees because they function as "price signals" that encourage drivers to buy more fuel efficient vehicles and/or drive fewer miles or move closer to their place of work. User fees have a dual advantage over other taxes. They can be set to reflect the benefits drivers receive from the system as well as the costs they impose on the system and the environment. User fees, then, are: “(1) effective because existing highway capacity is better utilized, congestion and emissions are reduced, and revenues rise and fall with system use; (2) efficient because highway construction and maintenance needs are minimized; and (3) equitable because light users of the transportation system are not forced to subsidize heavy users of the system" (Brown et al., 1999). The same logic applies to paying for roads with tolls and fees for commercial vehicles based on vehicle weight and other pertinent factors. Of course a perfect correspondence between use and payment is elusive; but we believe that this principle offers the best guidance for policy.

\section{THE ROOTS OF THE FUNDING CRISIS}

Many of the roads in the state highway systems are principal arterials, which carry heavy traffic loads. As Table 1 reveals, the lane miles of principal arterials grew dramatically from 351,350 in 1982 to 471,614 in 2007 , an increase of 34.2 percent over 25 years. Similarly, developed land also expanded by 56.8 percent over the same period. Clearly, sprawling development requires more lane miles of arterials, either in the form of new roads or expansion of two lane highways to four or more lanes. Some of these new arterials are the responsibility of local governments, as local governments have now become responsible for a larger percentage of arterials (Yusuf et al., 2011).

The states and local jurisdictions now have a substantially larger system to maintain. Fuel taxes are a large component of the state 
road funds, which states rely on for funds for new facilities and maintenance of the old. Table 1 shows that states confront two other obstacles to maintaining adequate revenues: a large increase in construction costs and virtually no increase in the gas tax rate, once the nominal gas tax rate is adjusted for inflation. From 1982 to 2007, the FHWA construction price index rose 150.1 percent while the average nominal gas tax rate rose 113.9 percent. Indeed, as Table 1 shows, the real gas tax rate (adjusted for general inflation)

TABLE 1

Some Factors behind the Funding Crisis in the States

\begin{tabular}{|c|c|c|c|c|c|}
\hline Year & 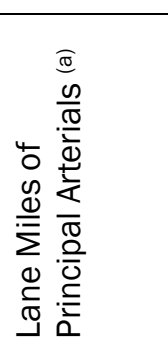 & 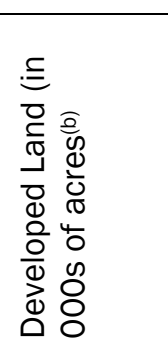 & 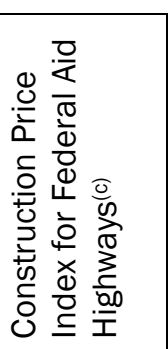 & 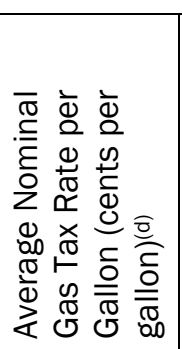 & 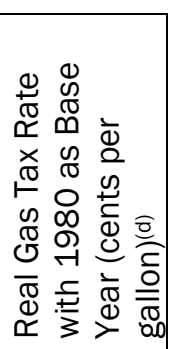 \\
\hline 1982 & 351,350 & $70,964.1$ & 88.5 & 10.1 & 8.5 \\
\hline 1987 & 370,297 & $76,871.0$ & 100 & 14.2 & 9.9 \\
\hline 1992 & 411,765 & $83,902.3$ & 105.1 & 18.6 & 11.0 \\
\hline 1997 & 431,943 & $94,577.9$ & 160.5 & 19.9 & 10.3 \\
\hline 2002 & 443,830 & $104,030.8$ & 179.9 & 20.2 & 9.3 \\
\hline 2007 & 471,614 & $111,251.2$ & $221.3 *$ & 21.6 & 8.6 \\
\hline $\begin{array}{l}\text { \% Change } \\
1982-2007\end{array}$ & $34.2 \%$ & $56.8 \%$ & $150.1 \%$ & $113.9 \%$ & $1.2 \%$ \\
\hline
\end{tabular}

Note: *Index discontinued after 2006. Data shown is the index value for 2006.

Sources:

(a) Lane miles of arterials from Table HM-210 of the Federal Highway Administration's Highway Statistics series;

(b) Developed land from National Resources Inventory (U.S. Department of Agriculture, 2009);

(c) Construction price index from the Federal Highway Administration (2007);

(d) Gasoline tax rates are the national average for the states from Table SF-2 of the Federal Highway Administration's Highway Statistics series. Real gas tax rates are adjusted using CPI-U from the Bureau of Labor Statistics. 
was almost identical in 1982 and 2007. If adjusted for construction price increases instead, the real gas tax rate would have actually declined. Thus, the increase in gas mileage is but one of the problems confronting the states. They have more lane miles to maintain and the rise in construction cost has substantially outstripped the rise in gas tax rates.

The expansion in the number of lane miles has led to a surge in spending for highways along with shifts in the pattern of spending. Table 2 presents changes in spending from 1980 to 2008 for total spending, in addition to spending for specific categories such as capital outlays, maintenance, and debt service. Total spending rose markedly over this period-an increase of $241 \%$. Capital outlay grew by a larger margin-309\%. Maintenance and services expenditures rose $303 \%$. But debt service rose even more, by $439 \%$.

Over this time period, as a percent of total spending, capital outlay, maintenance and services, and debt service expanded their share of total spending. Apparently, a larger road and highway

TABLE 2

State Spending on Highways from 1980 to 2008 in Dollars

\begin{tabular}{|c|c|c|c|c|c|c|c|}
\hline & 1980 & 1985 & 1990 & 1995 & 2000 & 2005 & 2008 \\
\hline $\begin{array}{l}\text { Total } \\
\text { spending on } \\
\text { highways (in } \\
\text { O00s) }\end{array}$ & 40,891 & 53,580 & 67,261 & 89,832 & 116,517 & 130,306 & 139,584 \\
\hline $\begin{array}{l}\text { Capital } \\
\text { outlay }\end{array}$ & 15,386 & 20,289 & 26,254 & 30,550 & 44,069 & 50,309 & 62,907 \\
\hline $\begin{array}{l}\text { Mainte- } \\
\text { nance \& } \\
\text { Services }\end{array}$ & 4,646 & 6,440 & 8,394 & 10,359 & 12,795 & 15,944 & 18,707 \\
\hline Debt service & 2,058 & 4,794 & 3,575 & 4,852 & 6,095 & 9,655 & 10,995 \\
\hline \multicolumn{8}{|c|}{ As $\%$ of total spending } \\
\hline $\begin{array}{l}\text { Capital } \\
\text { Outlay }\end{array}$ & $37.6 \%$ & $37.9 \%$ & $39.0 \%$ & $34.0 \%$ & $37.8 \%$ & $38.6 \%$ & $45.1 \%$ \\
\hline $\begin{array}{l}\text { Maintenance } \\
\& \text { Services }\end{array}$ & $11.4 \%$ & $12.0 \%$ & $12.5 \%$ & $11.5 \%$ & $11.0 \%$ & $12.2 \%$ & $13.4 \%$ \\
\hline $\begin{array}{l}\text { Debt } \\
\text { service }\end{array}$ & $5.0 \%$ & $8.9 \%$ & $5.3 \%$ & $5.4 \%$ & $5.2 \%$ & $7.4 \%$ & $7.9 \%$ \\
\hline
\end{tabular}

Note: All \$ values are nominal and in thousands (000s). 
system has prompted the states to devote proportionately more dollars to capital and maintenance and fostered a turn to increased borrowing.

Table 3 reveals the shifts in the sources of state funding for highways. Federal funds dropped from $38.4 \%$ to $23.3 \%$ of funding. Reliance on transfers from the general fund fluctuates but appears to be generally less than $5 \%$ of revenues, while toll revenues are fairly constant at approximately 5\%. Reliance on bonds has risen dramatically from 4.1 percent of revenues to 14.4 percent, which accounts for the rise in spending on debt service. The drop in

TABLE 3

Revenues for Highways from 1980 to 2008 in Dollars and by Percent: Total Spending, General Fund Appropriations, Federal Funds, Bond Proceeds, Tolls, Motor Fuel Taxes

\begin{tabular}{|c|c|c|c|c|c|c|c|}
\hline & 1980 & 1985 & 1990 & 1995 & 2000 & 2005 & 2008 \\
\hline Total revenues & 23,990 & 37,832 & 44,042 & 68,529 & 92,406 & 120,373 & 144,683 \\
\hline $\begin{array}{l}\text { State General } \\
\text { Fund } \\
\text { appropriations }\end{array}$ & 1,251 & 931 & 1,443 & 1,605 & 4,140 & 3,384 & 6,819 \\
\hline Federal funds & 9,204 & 11,619 & 13,557 & 19,091 & 24,149 & 28,813 & 33,694 \\
\hline $\begin{array}{l}\text { Bond } \\
\text { proceeds }\end{array}$ & 991 & 5,072 & 3,120 & 4,671 & 9,108 & 21,192 & 20,867 \\
\hline $\begin{array}{l}\text { Roads and } \\
\text { crossing tolls }\end{array}$ & 1,344 & 1,973 & 2,555 & 3,489 & 4,742 & 6,356 & 7,539 \\
\hline Motor fuels tax & 13,762 & 19,708 & 26,705 & 31,571 & 35,341 & 38,487 & 37,217 \\
\hline \multicolumn{8}{|c|}{ As \% of total revenues } \\
\hline $\begin{array}{l}\text { State General } \\
\text { Fund } \\
\text { appropriations }\end{array}$ & $5.2 \%$ & $2.5 \%$ & $3.3 \%$ & $2.3 \%$ & $4.5 \%$ & $2.8 \%$ & $4.7 \%$ \\
\hline Federal funds & $38.4 \%$ & $30.7 \%$ & $30.8 \%$ & $27.9 \%$ & $26.1 \%$ & $23.9 \%$ & $23.3 \%$ \\
\hline $\begin{array}{l}\text { Bond } \\
\text { proceeds }\end{array}$ & $4.1 \%$ & $13.4 \%$ & $7.1 \%$ & $6.8 \%$ & $9.9 \%$ & $17.6 \%$ & $14.4 \%$ \\
\hline $\begin{array}{l}\text { Roads and } \\
\text { crossing tolls }\end{array}$ & $5.6 \%$ & $5.2 \%$ & $5.8 \%$ & $5.1 \%$ & $5.1 \%$ & $5.3 \%$ & $5.2 \%$ \\
\hline Motor fuels tax & $57.4 \%$ & $52.1 \%$ & $60.6 \%$ & $46.1 \%$ & $38.2 \%$ & $32.0 \%$ & $25.7 \%$ \\
\hline $\begin{array}{l}\text { Other } \\
\text { Revenues }\end{array}$ & & & & 11.8 & 16.2 & 18.4 & $26.7 \%$ \\
\hline
\end{tabular}

Note: All \$ values are nominal and in thousands (000s). 
revenues from the fuel tax is precipitous-from $57.4 \%$ of revenues to $25.7 \%$.

These trends point to a widening gap between revenues and expenditures that is increasingly being financed through debt. Table 4 summarizes the gap between highway revenues (not including bond proceeds) and expenditures. This table shows that the states continually face a gap between revenues and expenditures, and that a larger percentage of the revenue gap is addressed through borrowing. In 1980, the revenue gap was $\$ 17,743,365$; of this gap, bond proceeds of $\$ 842,089$ constituted only a small portion of the revenue gap. In 2008, on the other hand, the revenue gap was $\$ 9,164,719$ and bond proceeds more than covered the gap.

TABLE 4

Revenue-Expenditure Gap and Use of Bond Proceeds to Finance the Gap, from 1980 - 2008

\begin{tabular}{|l|r|r|r|r|r|r|l|}
\hline & \multicolumn{1}{|c|}{1980} & 1985 & 1990 & 1995 & 2000 & 2005 & 2008 \\
\hline $\begin{array}{l}\text { Highway revenues } \\
\text { (less proceeds from } \\
\text { original bond } \\
\text { issuance) }\end{array}$ & 23,148 & 34,747 & 41,035 & 64,213 & 84,228 & 108,751 & 130,419 \\
\hline $\begin{array}{l}\text { Gap between } \\
\text { revenues (less } \\
\text { bond proceeds) \& } \\
\text { expenditures }\end{array}$ & $(17,743)$ & $(18,833)$ & $(26,226)$ & $(25,619)$ & $(32,289)$ & $(21,555)$ & $(9,165)$ \\
\hline $\begin{array}{l}\text { Bond proceeds } \\
\text { (original issues) }\end{array}$ & 842 & 3,085 & 3,006 & 4,317 & 8,178 & 11,622 & 14,264 \\
\hline $\begin{array}{l}\text { Bond proceeds as } \\
\% \text { of gap }\end{array}$ & $4.7 \%$ & $16.4 \%$ & $11.5 \%$ & $16.8 \%$ & $25.3 \%$ & $53.9 \%$ & $155.6 \%$ \\
\hline
\end{tabular}

Note: All \$ values are nominal and in thousands (000s).

Figure 1 sheds additional light on this trend of increased borrowing. This figure shows both the dollar amount of highway bonds outstanding (for all states) and highway bonds outstanding as a percent of total revenues (not including bond proceeds). Since 1985, highway bonds outstanding have increased as a percentage of total revenues, from $65 \%$ to $89 \%$ in 2008 . Similarly, in terms of dollar amounts, debt incurred by states for highways purposes has increased, from $\$ 20$ million and $\$ 21$ million in 1980 and 1985, respectively, to $\$ 111$ million in 2008 . 
FIGURE 1

Highway Bonds Outstanding for the States from 1980 to 2008

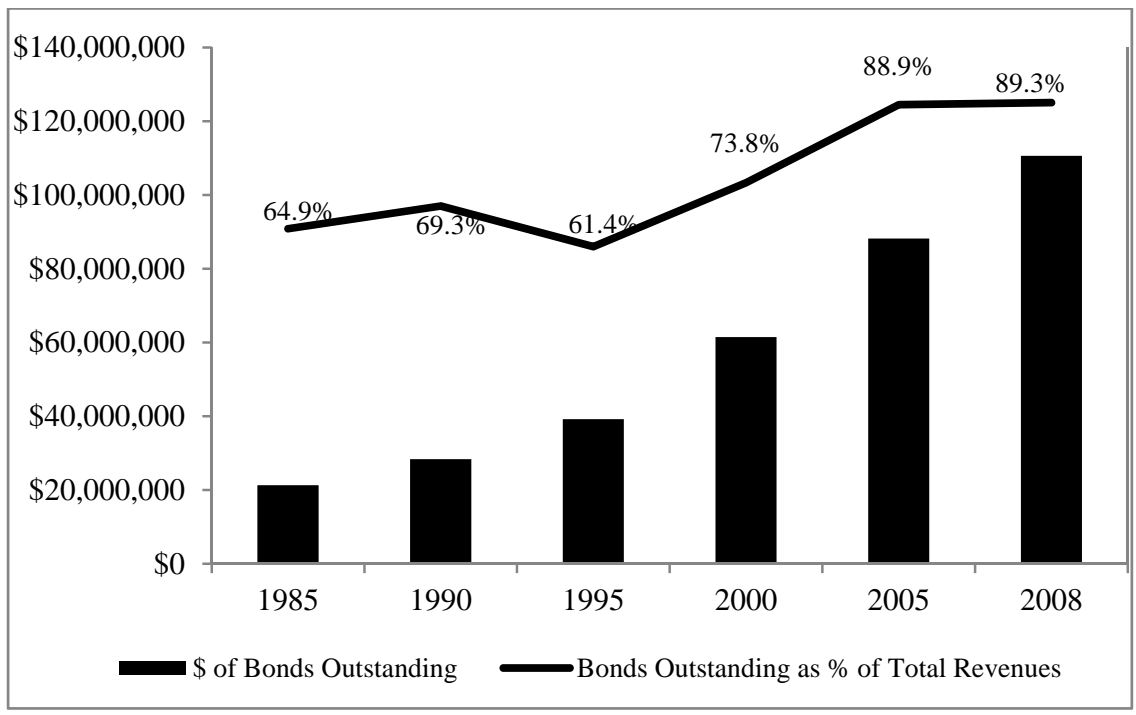

Two other challenges confront the states. With the passage of the Intermodal Surface Transportation Equity Act (ISTEA) in 1991 the federal government has shifted funding to a variety of new concerns (Goetz, 2007). Today the federal highway trust fund (HTP) provides funding for a number of programs, including transit, highway beautification, transportation enhancements such as bike lanes and pedestrian facilities, clean air standards, highway safety, bridge replacement, rail crossing protection, and safe routes to schools. Utt (2005) estimates that as much as 42 percent of fuel tax revenue in 2005 was diverted to programs that were not related to building or maintaining general purpose roads. The lion's share of diverted revenue (approximately 25\%) was for transit. Thus, a more holistic approach to transportation is emerging from the transition of highway departments into multi-modal organizations that work with metropolitan planning organizations and other local and regional planning agencies (Plant, 2008, Plant, 2007). This transition has resulted in state-level decision making that must consider multiple competing values and investments, including environmental quality, economic development, highway safety, congestion relief, equity and access for all groups, rational land use, passenger rail and bus 
transit, energy conservation, historic preservation, and the aesthetics of the built and natural environments.

States with metropolitan areas also confront the problem of rising congestion. According to the Texas Transportation Institute (TTI), the annual hours of delay per traveler in metropolitan areas increased from 16 hours in 1982 to 47 hours in 2003 (Utt, 2005). The TTI calculates a travel time index that measures the ratio of travel time in the peak travel period (rush hour) to the travel time at free-flow conditions. Free flow is defined as 60 miles per hour on freeways and $35 \mathrm{mph}$ on principal arterials. Thus a 20 minute free flow trip that takes 27 minutes at peak travel time has a ratio of 1.35. Across the 85 metropolitan areas studied by the TTI, the travel time index has increased from 1.12 in 1982 to 1.37 in 2003. There are various ways to cope with congestion, but clearly, some urban areas will want to add lane miles or build new facilities to cope with congestion.

\section{SOME RESPONSES BY THE STATES TO THE TRANSPORTATION FUNDING PROBLEM}

Facing the new environment for transportation funding, the states have responded in several ways to reduce their costs and raise revenue. As discussed above, they have not raised the real gas tax rate, but they have turned to more borrowing. They also appear to be shifting some of the burden of road building to local governments. (Yusuf et al. 2011) Between 1999 and 2007, the state highway system (in terms of miles of highways and roads) expanded by 6,579 miles (less than 1\%). In contrast, the local road system expanded by 93,769 miles or more than $3 \%$.

Another emerging strategy is intergovernmental in nature. State governments, having received less revenue from the federal government, have also begun to distribute less revenue to local governments (Yusuf et al., 2011). In the early 2000s, state transfers to local governments constituted approximately 35\% of local government revenues for roads. By 2006, this had dropped to as little as $20 \%$ of local government revenues, placing a heavier burden on local governments, which now have more roads to maintain with less financial assistance from their state governments.

Another strategy for coping with reduced revenue relative to the size and cost of building and maintaining the highway system, one in 
line with the shift to relatively more local responsibility for roads, is to downsize the state Departments of Transportation (DOTs). Table 5 shows that employment at state highway agencies (measured as fulltime equivalent or FTE employees) has declined by 1.9 percent despite the increase in responsibility. At the same time, the number of highway employees at the local level has grown by 12.4 percent. The ratio of state highway employees to local employees dropped precipitously; in 1992 it was 0.96 and in 1997 it was 0.83. By 2007, it had fallen to 0.79 .

TABLE 5

State and Local Highway Employment from 1982 to 2007

\begin{tabular}{|l|r|r|r|}
\hline Year & $\begin{array}{l}\text { State Highway } \\
\text { FTE employees }\end{array}$ & $\begin{array}{l}\text { Local Highway } \\
\text { FTE Employees }\end{array}$ & \multicolumn{1}{l}{$\begin{array}{l}\text { ltate FTE/ } \\
\text { Local FTE }\end{array}$} \\
\hline 1982 & 241,385 & 268,040 & .90 \\
\hline 1987 & 248,055 & 266,001 & .93 \\
\hline 1992 & 256,829 & 268,288 & .96 \\
\hline 1997 & 246,187 & 296,425 & .83 \\
\hline 2002 & 248,272 & 296,977 & .84 \\
\hline $\mathbf{2 0 0 7}$ & 236,758 & 301,143 & .79 \\
\hline Change, 1982-2007 & -4.627 & 33,103 & \\
\hline \% Change, 1982-2007 & -1.9 & 12.4 & \\
\hline
\end{tabular}

Source: FTE (full-time equivalent) employees from the U.S. Census Government Employment and Payroll Statistics (www.census.gov/govs/apes).

In this section we have discussed several approaches taken by the states that alleviate some of the financial burden for responsibility for a larger system with shrinking fuel tax revenues. The combined effects of these appear to be small and in the case of borrowing not sustainable. Moreover, estimates of future needs paint a bleak picture for transportation funding absent additional revenues. The Forum on Funding and Financing Solutions for Surface Transportation in the Coming Decade organized by the AASHTO Center for Excellence in Project Finance (AASHTO Center for Excellence in Project Finance, 2011) reviewed six estimates of average annual capital needs and funding gaps, all of which concluded that investment needs far outpace predicted revenues 
over the 2008-35 time frame. Similarly, the National Surface Transportation Infrastructure Financing Commission (n.d.) estimates that the current revenue system will meet only $44 \%$ of the requirements to maintain our roads and bridges and only $36 \%$ of the costs to improve them.

\section{INCREASING REVENUE WITH A VARIABLE RATE FUEL TAX AND AN ESAL-MILE TAX ON TRUCKS}

In this section we discuss two ways to increase highway revenues. Given the state of the technology and its application, and following the lead of others, we assume that a vehicle miles travelled (VMT) fee is not yet practicable, and therefore fuel taxes paid per gallon purchased will continue to be needed for some time.

As discussed previously, the ability of motor fuel tax revenues to cover transportation infrastructure costs has declined. This is due to three important factors: (a) marked increases in vehicle fuel efficiency; (b) a surge in construction costs for highway projects and in automobile use; and (c) the fixed per gallon gas tax does not change with inflation. However, as we show next, it is possible to index the gas tax rate to take into account inflationary pressures as well as improvements in fuel efficiency.

Table 6 presents a comparison of the mean gas tax rate of the states that have a variable rate gas tax to that of the states (and the District of Columbia) with the traditional, non-variable fixed rates. The variable rate states are: Florida, lowa, Kentucky, Maine, Nebraska, New York, North Carolina, West Virginia, and Wisconsin. States with a variable rate had higher gas tax rates. From 1980 to 2009, the nominal gas tax rate for states with a fixed rate rose from 8.8 cents to 20.9 cents per gallon. In states with a variable rate it rose from 10.5 cents to 26.2 cents per gallon. Thus the states with variable rates were able to raise more revenue per gallon purchased.

\section{Simulating Different Methods for Indexing the Gas Tax}

We have argued that the funding crisis has multiple sources. We simulate an indexed gas tax structure that takes several of them into account to find the most effective way of indexing. This simulation is described in depth in Yusuf and O'Connell (2013) and is summarized 
TABLE 6

Average Gasoline Tax Rates from 1980-2009 (in Cents per Gallon) for States with Traditional, Fixed Tax Rates and States with Variable Rates)

\begin{tabular}{|l|c|c|}
\hline Year & Fixed Rate States & Variable Rate States \\
\hline 1980 & 8.8 & 10.5 \\
\hline 1985 & 12.0 & 13.6 \\
\hline 1990 & 16.4 & 18.5 \\
\hline 1995 & 19.0 & 21.3 \\
\hline 2000 & 20.0 & 20.0 \\
\hline 2005 & 20.6 & 23.4 \\
\hline 2008 & 21.0 & 25.7 \\
\hline 2009 & 20.9 & 26.2 \\
\hline
\end{tabular}

Note: All \$ values are nominal.

Source: Federal Highway Administration (multiple years), Highway Statistics Table MF-205.

next. To account for greater utilization of the transportation system, we look at revenue adequacy from the perspectives of motor fuel tax revenue per 1000 vehicle-miles-traveled (VMT). In 1993, gas tax revenues were $\$ 8.98$ per 1000 VMT and have since been steadily declining in real terms. By 2008 , this revenue was only $\$ 6.06$ per 1000 VMT (in 1993\$), highlighting the inability of the traditional, fixed rate gas tax to generate adequate revenue.

\section{Four Variable Rate Structures}

Using aggregate, national level analysis we simulate four variable rate structures based on three multipliers (M) to adjust the gas tax rates. These multipliers are linked to the FHWA Construction Cost Index $\left(\mathrm{M}_{\mathrm{FHWA}}\right.$ Cost Index $)$, the $\mathrm{CPI}\left(\mathrm{M}_{\mathrm{CPI}}\right)$, and fuel efficiency $\left(M_{\text {Fuel Efficiency }}\right)$. See Appendix $A$ for the calculations of these multipliers.

These multipliers are used to formulate four variable rate gas tax structures that index the gas tax rate to inflation and fuel efficiency. The method of calculating the gas tax rates $(T)$ under the different structures are shown in Appendix A. 
Table 7 summarizes the gas tax rates under these four variable structures, compared to the actual tax rate. All four variable rate structures resulted in tax rates that were higher than the actual tax rate.

TABLE 7

Gas Tax Rates in Cents per Gallon

\begin{tabular}{|c|c|c|c|c|c|}
\hline \multirow[b]{2}{*}{ Year } & \multirow[b]{2}{*}{$\begin{array}{l}\text { Actual } \\
\text { Tax Rate } \\
\text { (in } \\
\text { Nominal } \\
\text { Terms) } \\
\end{array}$} & \multicolumn{4}{|c|}{$\begin{array}{l}\text { Simulated Gas Tax Rates Under Different } \\
\text { Variable Rate Structures }\end{array}$} \\
\hline & & \begin{tabular}{|l|} 
Indexed to \\
FHWA \\
Cost \\
\end{tabular} & $\begin{array}{l}\text { Indexed } \\
\text { to CPI }\end{array}$ & $\begin{array}{l}\text { Indexed to } \\
\text { FHWA Cost \& } \\
\text { Fuel } \\
\text { Efficiency }\end{array}$ & $\begin{array}{l}\text { Indexed to } \\
\text { CPI \& Fuel } \\
\text { Efficiency }\end{array}$ \\
\hline 1993 & 17.55 & 17.55 & 17.55 & 17.55 & 17.55 \\
\hline 1994 & 17.99 & 18.08 & 18.08 & 17.61 & 17.60 \\
\hline 1995 & 18.34 & 19.22 & 18.54 & 19.11 & 18.43 \\
\hline 1996 & 18.51 & 20.36 & 19.06 & 19.91 & 18.65 \\
\hline 1997 & 18.50 & 20.07 & 19.63 & 19.80 & 19.36 \\
\hline 1998 & 18.67 & 21.81 & 20.08 & 21.71 & 19.98 \\
\hline 1999 & 19.05 & 21.19 & 20.39 & 20.99 & 20.20 \\
\hline 2000 & 19.96 & 22.79 & 20.84 & 22.58 & 20.65 \\
\hline 2001 & 19.29 & 24.31 & 21.54 & 24.76 & 21.94 \\
\hline 2002 & 20.17 & 24.18 & 22.15 & 24.74 & 22.67 \\
\hline 2003 & 19.07 & 24.70 & 22.50 & 25.27 & 23.02 \\
\hline 2004 & 19.13 & 25.01 & 23.02 & 25.79 & 23.73 \\
\hline 2005 & 19.25 & 25.78 & 23.63 & 26.91 & 24.66 \\
\hline 2006 & 20.30 & 30.66 & 24.43 & 32.47 & 25.87 \\
\hline 2007 & 19.25 & 30.52 & 25.22 & 31.80 & 26.27 \\
\hline 2008 & 20.48 & 30.00 & 25.94 & 31.25 & 27.02 \\
\hline
\end{tabular}

Beyond the tax rate the revenues generated by the different rate structure are also critical for understanding the sustainability of the gas tax. The tax revenues were calculated by multiplying the gas tax rate by the actual gallons of gasoline taxed in the given year. Figure 2 compares the different variable gas tax rates in terms of the dollar 
FIGURE 2

Gas Tax Revenues in Real Terms (in 1993 dollar value), Actual vs. Variable Rates

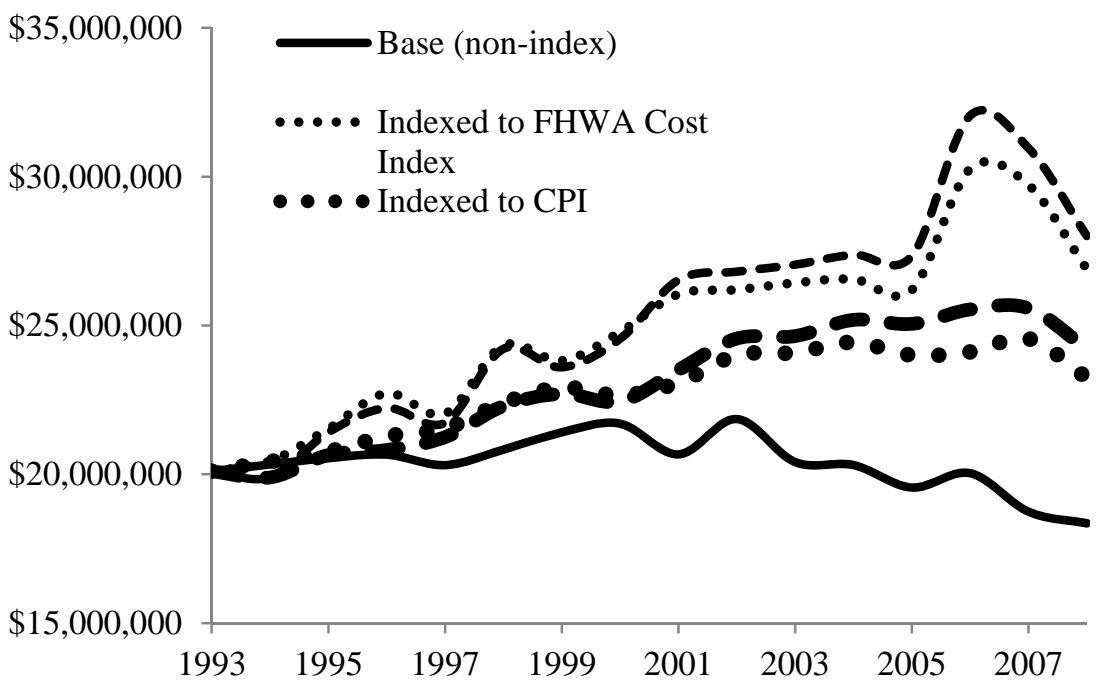

amount of revenue generated. Actual gas tax revenues have declined in real terms since 1993, but the variable rate structures can generate gas tax revenues that could potentially exceed the 1993 revenue level. Note that this approach does not account for tax price elasticity of the gas tax, which might cause the amount of gasoline purchased to be lower as the tax rate increases. Therefore, this approach only slightly overestimates the revenue generation ability of the variable rate gas tax, as recent experience with large increases in gas prices suggests that the relatively small differences in tax rates discussed here would have little impact on demand when added to the price of gasoline at the pump.

The need to invest in highway maintenance grows with increases in VMT. It is important, therefore, to analyze revenues in terms of dollars per VMT. The comparison of gas tax revenues in terms of dollars per thousand VMT is provided in Figure 3 . While this chart also shows how the actual gas tax has not been able to maintain revenues per VMT, it further highlights how only one of the four variable rate gas tax structures, the one indexed to both the FHWA 
cost index and fuel efficiency, may generate gas tax revenue per VMT that keeps pace with 1993 levels.

FIGURE 3

Gas Tax Revenues per Thousand Vehicle-Miles-Traveled

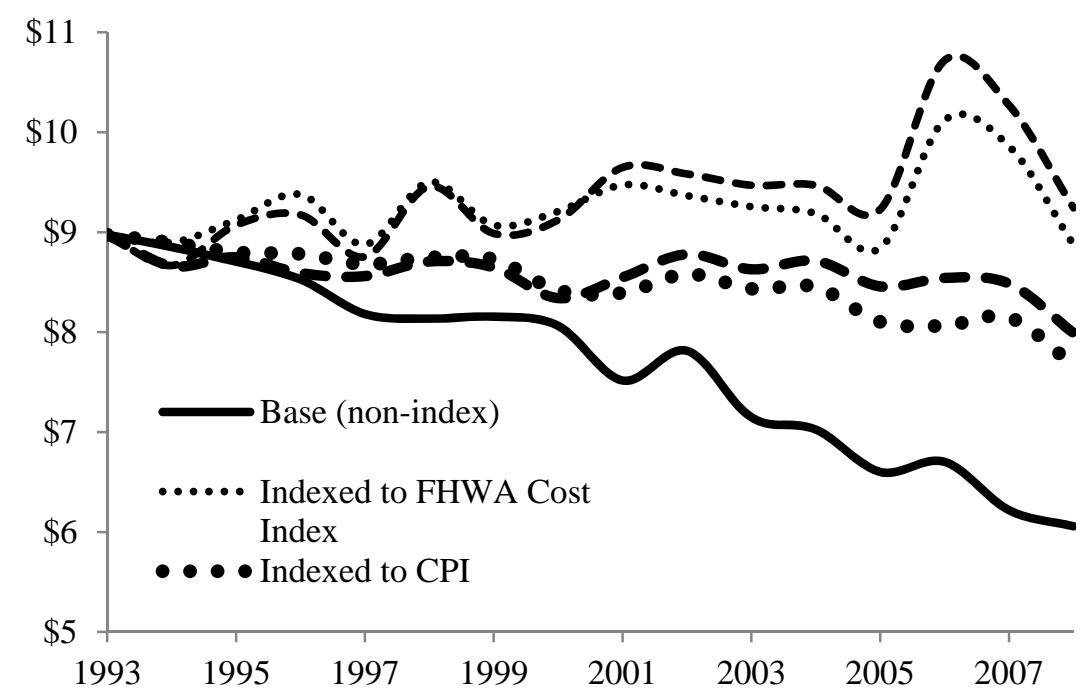

\section{Restructuring the Taxes on Commercial Carriers}

In 2001 the federal HTF had the following breakdown of sources: gasohol (9\%), diesel (24\%), gasoline (58\%), and truck-related (9\%). The truck-related taxes have three categories that impose taxes on heavier vehicles and tires for heavier vehicles. The tire tax, for example, increases from no tax on tires weighing 40 or fewer pounds to $\$ 10.50$ for 90 pounds plus $\$ .50$ per pound in excess of 90 pounds. The truck and trailer sales tax is $12 \%$ of the retailer's sales price for tractors and trucks over 33,000 pounds gross vehicle weight and trailers over 26,000 GVW. The heavy vehicle weight tax is an annual tax on trucks 55,000 pounds and over GVW-a tax of $\$ 100$ plus $\$ 22$ for each 1,000 pounds (or fraction thereof) in excess of 55,000 pounds (up to a maximum tax of $\$ 550$ ).

This tax structure is quite inadequate when the damage to highways caused by large commercial vehicles with heavy loads is 
taken into account (Brown et al., 1999, Winston, 1991). Pavement damage is a function of vehicle weight per axle. The damage caused by an axle is defined in terms of equivalent standard axle loads (esal) causing the same damage. The standard is set at a single axle of 18,000 . Winston reports that "...the rear axle of a typical 13-ton van causes over 1000 times as much damage as that of a car" (1991).

Consistent with the logic of imposing user charges to pay for highways, Winston presents the rationale for restructuring the tax burden on trucks to better align taxes with the damage to roadways produced by commercial carriers: "The efficient marginal cost pricing rule recognizes that when infrastructure users make travel decisions, they will ignore their contributions to... infrastructure wear. As a result, the social costs of a trip will exceed private costs, and the infrastructure authority must therefore set... infrastructure wear charges to close this gap" (1991). The National Cooperative Highway Research Program calculated the average maintenance cost per esalmile to be 1.6 cents (Transportation Research Board, 1986). Assuming a slightly lower esal-mile cost of 1.5 cents on a rural interstate, "a truck equivalent to 2 standard axles traveling 100 miles on a rural interstate would accrue 200 esal-miles and a charge of \$3" (Winston 1991, p.116).

An esal-miles tax would raise more revenue than the current system. It would have the added advantage of moving some freight shipments to rail and barge. In addition, it would provide an incentive to use trucks with lower loads per axle or trucks with more axles. Thus, it would decrease the damage to highways in addition to generating more revenue. Such a tax is recommended by a number of researchers (Brown et al., 1999, U.S. General Accounting Office, 2002).

\section{SUMMARY AND CONCLUSION}

The current crisis in spending for highways has multiple roots in addition to the rise in vehicle fuel efficiency. Sprawling development and the expansion of the number of lane miles in the state highway systems along with a significant rise in vehicle ownership have vastly increased the total vehicle miles travelled each year in the United States- with the result that total spending on infrastructure has risen dramatically. The states have responded to the crisis in transportation financing in many ways. The ones discussed in section 
two of this article have no doubt helped; but they are limited. Debtfinancing is costly, especially for maintenance, delays in which only increase costs as infrastructure deteriorates at accelerated rates. The slowdown in new highway construction also helps to mitigate the funding crisis, as cities and states turn to the various policies referred to as smart growth such as infill development, transit oriented development, light rail, growth boundaries, purchase of development rights and the like (O'Connell, 2009). But construction costs are up and estimates of future needs indicate that new sources of revenue must be found.

The cuts in federal spending appear to be permanent and are difficult to replace. In fact, Nesbit and Kreft (2009) found that federal grants do not crowd-out state spending on highways. Thus, one-dollar in federal highway aid increases state highway spending by approximately one dollar. One implication of this is that cuts in federal grants will require increases in state taxes or bonds. We presented the case for two methods for increasing revenues: a variable rate tax indexed to construction costs and average fleet fuel efficiency and the esal-miles tax for commercial carriers. Both of these are user taxes that would decrease VMT. Both would reduce damage to the highway, especially the wear and tear from heavy trucks.

\section{REFERENCES}

AASHTO Center For Exellence In Project Finance (2011). "The Forum on Funding and Financing Solutions for Surface Transportation in the Coming Decade: Conference Report." Washington, DC: American Association of State Highway and Transportation Officials.

Brown, J., Defranco, M., Hill, M. C., Law, P., Olson, J., Taylor, B. D., Wachs, M. \& Weinstein, A. (1999). The Future of California Highway Finance. [Online]. Berkeley, CA: California Policy Research Center, University of California. [Online]. Available at www.its.ucla.edu/research/pubs/highway.pdf [Retrieved October 5, 2011].

Bureau of Transportaion Statistics (2010). Table 4-11: Passenger Car and Motorcycle Fuel Consumption and Travel. [Online]. Washington, DC: U.S. Department of Transportation, Research and Innovative Technology Administration. [Online]. Available at 
http://www.bts.gov/publications/national_transportation_statisti cs/2010/html/table_04_11.html [Retrieved November 8, 2011].

Federal Highway Administration (2007). Price Trends for Federal-Aid Highway Construction, Fourth Quarter 2006. Washington, DC: Author.

Goetz, A. (2007). "State Departments of Transportation: From Highway Departments to Transportation Agencies." In J. F. Plant (Ed.), Handbook of Transportation Policy and Administration (pp. 121-144). New York: CRC Press.

National Surface Transportation Infrastructure Financing Commision. Paying Our Own Way: A New Framework for Transportation Finance. [Online]. Washington, DC: National Surface Transportation Infrastructure Financing Commission. [Online]. Available at http://financecommission.dot.gov/Documents/ NSTIF_Commission_Final_Report_MarO9FNL.pdf. [Retrieved March 15, 2011].

Nesbit, T. M. \& Kreft, S. F. (2009). "Federal Grants, Earmarked revenues, and Budget Crowd-Out: State Highway Funding." Public Budgeting and Finance, 29(2): 94-110.

O'Connell, L. (2009). "The Impact of Local Supporters on Smart Growth Policy Adoption." Journal of the American Planning Association, 75(3): 281-291.

Plant, J. F. (2007). "The Big Questions of Transportation Policy and Administration in the Twenty-first Century." In Plant, J. F. (Ed.), Handbook of Transportation Policy and Administration (pp. 3-8). New York: CRC Press.

Plant, J. F. (2008). "Transportation Policy." Encyclopedia of Public Administration and Public Policy. Boca Raton, FL: Taylor \& Francis.

Transportation Research Board (1986). National Cooperative Highway Research Program, Relationship Between Vehicle Configurations and Highway Design. Washington, DC: National Research Council.

U.S. Department of Agriculture (2009). Summary Report: 2007 National Resources Inventory. [Online]. Washington, DC: Natural Resources Conservation Service. [Online]. Available at 
http://www.nrcs.usda.gov/technical/NRI/2007/2007_NRI_Sum mary.pdf. [Retrieved January 24, 2013].

U.S. General Accounting Office (2002). Highway Financing: Factors Affecting Highway Trust Fund Revenues. Washington, DC: U.S. General Accounting Office.

Utt, R. D. (2005). "Will a Bigger Role for States Improve Transportation Policy Performance?" In Cox, W., Pisarski, A. \& Utt, R. D. (Eds.), 21st Century Highways: Innovative Solutions to America's Transportation Needs (pp. 163-182). Washington, DC: Heritage.

Winston, C. (1991). "Efficient Infrastructure Policy." Journal of Economic Perspectives, 5(1): 113-127.

Yusuf, J.E. \& O'Connell, L. (2013). “Improving Revenue Adequacy by Indexing the Gas Tax to Indicators of Need: A Simulation Analysis." Public Works Management \& Policy, 18(3): 230-244.

Yusuf, J.E., O'Connell, L. \& Abutabenjeh, S. (2011). "Paying for Locallyowned Roads: A Crisis in Local Government Highway Finance." Public Works Management \& Policy, 16(3): 250-269.

\section{APPENDIX 1}

\section{Calculation of Indexing Multipliers and Indexed Gas Tax Rates}

Indexing Multipliers

For $\mathrm{t}=1993$ :

$$
\mathrm{M}_{\mathrm{FHWA} \text { Cost Index,t }}=\mathrm{M}_{\mathrm{CPI}, \mathrm{t}}=\mathrm{M}_{\text {Fuel Efficiency, } \mathrm{t}}=1
$$

For $\mathrm{t}=1994$ through 2008:

1

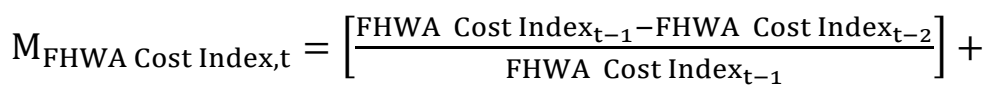

$$
\begin{aligned}
& \mathrm{M}_{\mathrm{CPI}, \mathrm{t}}=\left[\frac{\mathrm{CPI}_{\mathrm{t}-1}-\mathrm{CPI}_{\mathrm{t}-2}}{\mathrm{CPI}_{\mathrm{t}-1}}\right]+1 \\
& \mathrm{M}_{\text {Fuel Efficiency,t }}=\frac{\text { Fuel Efficiency } \mathrm{t}-1}{\text { Fuel Efficiency } \mathrm{t}-2}
\end{aligned}
$$

Indexed Gas Tax Rates

For $\mathrm{t}=1993$ : 
$\mathrm{T}_{\mathrm{FHWA} \text { Cost Index, }}=\mathrm{T}_{\mathrm{CPI}, \mathrm{t}}=\mathrm{T}_{\text {Fuel Efficiency, } \mathrm{t}}=\mathrm{T}_{1993}$ where $T_{1993}$ is the actual gas tax rate for 1993 .

For $\mathrm{t}=1994-2008$ :

$\mathrm{T}_{\mathrm{FHWA} \text { Price Index, } \mathrm{t}}=\mathrm{T}_{\mathrm{FHWA} \text { Price Index }, \mathrm{t}-1} \times \mathrm{M}_{\mathrm{FHWA} \text { Cost Index }, \mathrm{t}}$

$\mathrm{T}_{\mathrm{CPI}, \mathrm{t}}=\mathrm{T}_{\mathrm{CPI}, \mathrm{t}-1} \times \mathrm{M}_{\mathrm{CPI}, \mathrm{t}}$

$\mathrm{T}_{\text {FHWA Cost Index \& Fuel Efficiency, } t}=\mathrm{T}_{\mathrm{FHWA} \text { Cost Index }, \mathrm{t}-1} \times$

$\underline{\mathrm{M}_{\mathrm{FHWA}} \text { Cost Index,t }}$

MFuel Efficiency,t

$$
\mathrm{T}_{\mathrm{CPI} \& \text { Fuel Efficiency,t }}=\mathrm{T}_{\mathrm{CPI}, \mathrm{t}-1} \times \frac{\mathrm{M}_{\mathrm{CPI}, \mathrm{t}}}{\mathrm{M}_{\text {Fuel Efficiency }, \mathrm{t}}}
$$

